\title{
73. Preliminary Notes on Abnormalities Induced by Velban in Developing Mouse Embryos*)
}

By Eiji OHzU and Ryujiro SHoJI

(Comm. by Yoshimaro TanaKa, M.J.A., April 12, 1965)

Following recent studies by Gillitte and Bodenstein (1946), Bodenstein (1957), Cardinali et al. (1961, 1963), Ferm (1963 a, 1963 b), effects of mitotic inhibitory agents on mammalian embryos have been increasingly becoming the subject of special interest of current investigators, particularly in the field of teratology. Because of the fact that some of them have been therapeutically used agents, it may not be uncalled for to examine their teratogenic effect in mammals.

Velban (vinblastine sulfate, Lilly), known as a new alkaloid antitumor agent extracted from Vinca rosea Linn., was noted to exert as antimitotic effect in the bone marrow of the mouse (Cardinali et al. 1963). It was already shown by Ferm (1963 a) that administration of Velban to pregnant hamsters produced high incidence of dead embryos together with a few types of malformations.

This report deals with the study of the effect of Velban on developing mouse embryos following its administration to pregnant mice, with special regard to the malformations.

Material and methods: Mice, aged nearly 60 days, of MT and dd strains were used for experiments. Oestrous females inspected by means of vaginal smears were mated to male mice of the same strain. After mating the females were examined for the presence of vaginal plugs as a sign of successful copulation. Pregnant females received a daily dose of $2.5 \mathrm{mg} / \mathrm{kg}$ of Velban solution by subcutaneous injection from the 11th of 14th day of gestation. Control pregnant females were injected subcutaneously with similar volumes of saline solution during the same period of gestation. Velban was kindly supplied by Mr. T. Takahashi.

All females were killed on the 18th day of gestation in order to examine the condition and development of foetuses. Dead foetuses were classified grossly in the following two groups: a) dead foetuses which died before the 10th day of gestation (early death), and b) dead foetuses which died after the 11th day of gestation (late death).

*) Contribution No. 689 from the Zoological Institute, Faculty of Science, Hokkaido University, Sapporo. Supported partly by a grant-in-aid for the Scientific Research from the Ministry of Education, and partly by a financial aid to Dr. Y. Kimura from the Chugai Pharmaceutical Co. Ltd. 
All foetuses preserved in 70 per cent alcohol were examined for the occurrence of malformations.

Results: The results of the present experiments are summarized in Table I. Several types of abnormalities were observed in both experimental and control groups. The abnormalities obtained were as follows: exencephaly, harelip, hindfoot polydactyly and forefoot polydactyly (Figs. 1-4). The former three were found in MT strain, whereas the latter anomaly was observed in dd strain. Anomalies with exencephaly and forefoot polydactyly occurred with high incidence in both control and experimental groups. On the other hand, foetuses with harelip and hindfoot polydactyly occurred only in the experimental group, though the frequency was low. Such abnormalities may be caused by the treatment with Velban, since they were never observed in the control group.

Table I. Abnormal foetuses obtained from pregnant females treated with Velban and with saline as control ${ }^{\text {a) }}$

\begin{tabular}{|c|c|c|c|c|c|c|c|c|c|}
\hline Strain & $\begin{array}{c}\text { Dosage } \\
(\mathrm{mg} / \mathrm{kg})\end{array}$ & $\begin{array}{l}\text { No. of } \\
\text { preg- } \\
\text { nancy }\end{array}$ & $\begin{array}{l}\text { No. of } \\
\text { implan- } \\
\text { tation }\end{array}$ & $\begin{array}{l}\text { No. of } \\
\text { early } \\
\text { death }\end{array}$ & $\begin{array}{l}\text { No. of } \\
\text { late } \\
\text { death }\end{array}$ & $\begin{array}{l}\text { No. of } \\
\text { exen- } \\
\text { cephaly }\end{array}$ & $\begin{array}{l}\text { No. of } \\
\text { hare- } \\
\text { lip }\end{array}$ & $\begin{array}{l}\text { No. of } \\
\text { hind- } \\
\text { foot } \\
\text { poly- } \\
\text { dactyly }\end{array}$ & $\begin{array}{l}\text { No. of } \\
\text { fore- } \\
\text { foot } \\
\text { poly- } \\
\text { dactyly }\end{array}$ \\
\hline \multirow{2}{*}{$\mathrm{MT}$} & 2.5 & 16 & 99 & $\begin{array}{c}3 \\
(3.1)\end{array}$ & $\begin{array}{c}7 \\
(7.1)\end{array}$ & $\begin{array}{r}16^{\text {b) }} \\
(16.1)\end{array}$ & $\begin{array}{c}4 \\
(4.0)\end{array}$ & $\begin{array}{c}1 \\
(1.0)\end{array}$ & 0 \\
\hline & $\begin{array}{c}0 \\
\text { (Saline } \\
\text { only } \\
\text { control) }\end{array}$ & 23 & 123 & $\begin{array}{c}7 \\
(5.7)\end{array}$ & $\begin{array}{c}1 \\
(0.8)\end{array}$ & $\begin{array}{c}15 \\
(12.4)\end{array}$ & 0 & 0 & 0 \\
\hline \multirow{2}{*}{$\mathrm{dd}$} & 2.5 & 23 & 172 & $\begin{array}{c}6 \\
(3.5)\end{array}$ & $\begin{array}{c}7 \\
(4.1)\end{array}$ & 0 & 0 & 0 & $\begin{array}{c}19 \mathrm{c}) \\
(11.0)\end{array}$ \\
\hline & $\begin{array}{c}0 \\
\text { (Saline } \\
\text { only } \\
\text { control) }\end{array}$ & 22 & 179 & $\begin{array}{c}4 \\
(2.2)\end{array}$ & $\begin{array}{c}9 \\
(5.0)\end{array}$ & 0 & 0 & 0 & $\begin{array}{c}22 \\
(12.3)\end{array}$ \\
\hline
\end{tabular}

a) The parenthesized value represents the percentage for the number of implantation.

b, c) The results of " $t$ " test are insignificant between the experimental and control groups. For statistical treatment of the data, further study is needed with sufficient material, now being in progress.

It was also shown that dead foetuses (including early and late death) were observed in both control and experimental groups. There was no difference in the frequency of early death between the control and the experimental groups in both MT and dd strains. On the other hand, the frequency of late death in MT strain increased in the experimental group when compared with that in the control group. Evidence seems to imply that embryos of $\mathrm{MT}$ strain mice were more affected by the treatment of the drug than those of dd mice. 
Discussion: Ferm (1963a) studied teratogenic effects of Velban on foetuses in pregnant hamsters on the 8th day after gestation under various doses, and reported the high foetal mortality together with a few types of malformations occurring in the experimental group: malformations described are microphthalmia, anophthalmia and rib defects. He further noted that the foetal mortality rate increased in the experimental group treated with this agent at a dose level from 0.5 to $2.6 \mathrm{mg} / \mathrm{kg}$. The results obtained in the present experiments

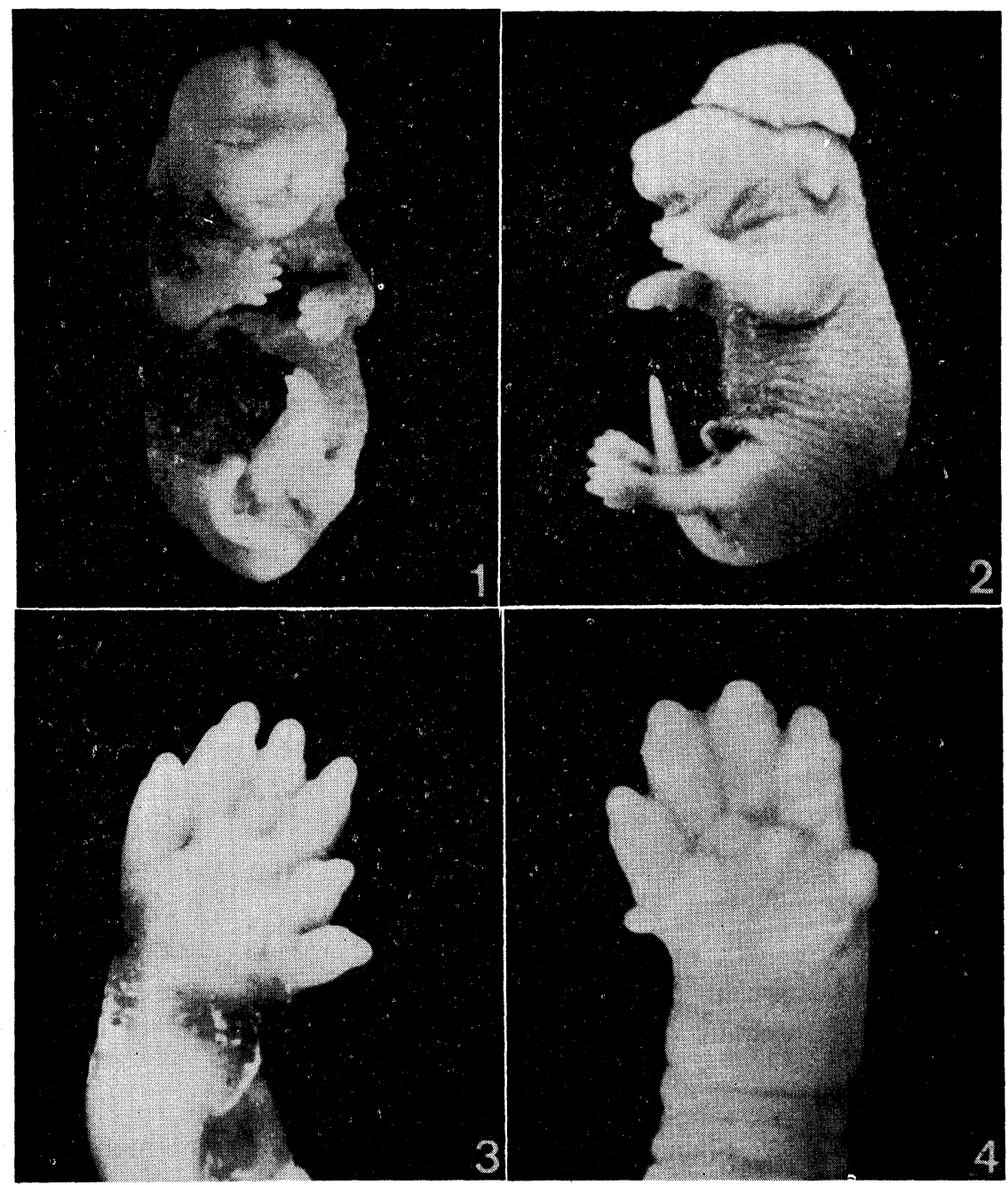

Fig. 1. Velban-induced harelip, from a experimental female of MT strain. Fig. 2. Spontaneous exencephaly, from a control female of MT strain. Fig. 3. Velban-induced hindfoot polydactyly, from a experimental female of MT strain. Fig. 4. Spontaneous forefoot polydactyly, from control female of dd strain. 
indicate that the incidence of dead and abnormal foetuses of MT strain increases in the experimental group. The rate of dead foetuses in the present study was less than that reported by Ferm (1963 a), although the rate of abnormality was similar. Discrepancy may be ascribable to the different sensitivity of the embryos during developmental stages.

Ferm (1963a) expressed a view on effects of cancer chemotherapeutic agents on pregnant hamsters, stating that the common teratogenic action of those agents might be caused by their mitosisarresting activity on developing embryonic tissue. Shoji and Kimura (1964) studied the antimitotic activity of Velban in tumor cells, and described that Velban exerted considerable influence upon tumor cells in the course of mitosis both in vivo and in vitro. It seems that abnormal foetuses obtained in the present experiments are induced by the action of the agent through a similar mechanism, thus supplementing the view of Ferm (1963a).

Interesting is that, within the scope of this experiment, only treated mice of MT strain showed abnormalities with harelip and polydactyly, and that in dd strain there was no particular difference in the incidence of anomalies between control and experimental groups. Cardinali et al. (1961) reported on the basis of in vivo studies that the stathmokinetic effect of antimitotic agent differed in mice, rats and other animals. The results of the present experiments indicate that the effect of Velban on developing mouse embryos differs by different strains of mice.

In conclusion, effects of Velban on 11- to 14-day mouse embryos of MT and dd strains were studied with special regard to the incidence of abnormal embryos and the death of foetuses. Anomalies with exencephaly occurred spontaneously in foetuses of MT strain, and forefoot polydactyly appeared only in dd strain mice. On the other hand, abnormalities with harelip and hindfoot polydactyly occurred exclusively in the experimental group of MT strain mice. The frequency of late death of foetuses was higher in treated females of MT strain than in control animals. It seems likely that the effects of Velban on developing mouse embryo differ by different strains of mice.

The authors wish to express their sincere gratitude to Professor Sajiro Makino for his direction and for going through the manuscript. Further cordial thanks are offered to Drs. Eizi Momma, Akiko Sato, Akio A. Awa, and Yanagi Kimura for their valuable advice and important criticism. 


\section{References}

Bodenstein, D. (1957): J. Exp. Zool., 104, 311-342.

Cardinali, G., G. Cardinali, A. H. Handler, and M. G. Agrifoglio (1961): Proc. Soc. Exp. Biol. and Med., 107, 891-892.

Cardinali, G., G. Cardinali, and M. A. Enein (1963): Blood, 21, 102-110.

Ferm, V. H. (1963a): Science, 141, 426.

Ferm, V. H. (1963b): Proc. Soc. Exp. Biol. and Med., 112, 775-778.

Gillitte, A., and D. Bodenstein (1946): J. Exp. Zool., 103, 1-32.

Shoji, R., and Y. Kimura (1964): Jour. Fac. Sci. Hokkaido Univ. Ser. VI Zool., 15, 353-359. 